\title{
Water diversions facilitate spread of non-native species
}

\author{
Aibin Zhan $\cdot$ Lei Zhang $\cdot$ Zhiqiang Xia $\cdot$ Ping Ni $\cdot$ \\ Wei Xiong • Yiyong Chen • G. Douglas Haffner • \\ Hugh J. MacIsaac
}

Received: 25 June 2015/Accepted: 6 July 2015/Published online: 10 July 2015

(C) Springer International Publishing Switzerland 2015

\begin{abstract}
Many countries/areas are experiencing or may soon experience water scarcity owing to rapid population growth, urbanization and/or climate change. Currently, almost one-fifth of the world's population (1.2 billion) live in areas of physical water scarcity. Water diversions have become a commonplace solution proposed by governments for alleviation of physical water scarcity. Thus far, more than 80 major projects are completed or under construction globally, including the world's largest diversion: South-to-North Water Transfer Project (SNWTP) in China. Negative effects associated with water diversions, such as habitat loss and transfer of pollutants, have been recognized. However, it has been largely
\end{abstract}

A. Zhan $(\bowtie) \cdot$ P. Ni · W. Xiong $\cdot$ Y. Chen

Research Center for Eco-Environmental Sciences, Chinese Academy of Sciences, 18 Shuangqing Road, Beijing 100085, China

e-mail: zhanaibin@hotmail.com; azhan@rcees.ac.cn

L. Zhang - Z. Xia - G. Douglas Haffner - H. J. MacIsaac China-Canada Three Gorges Reservoir Water Science Center, Southwest University, 1 Tiansheng Road, Beibei, Chongqing 400715, China

L. Zhang · G. Douglas Haffner

Faculty of Resources and Environment, Southwest University, 1 Tiansheng Road, Beibei,

Chongqing 400715, China

L. Zhang - Z. Xia - G. Douglas Haffner - H. J. MacIsaac Great Lakes Institute for Environmental Research, University of Windsor, Windsor, ON N9B 3P4, Canada overlooked that "invasion highways" are created when water diversions link biogeographic regions. These "invasion highways" can facilitate spread of an array of non-native species. Although previous experiences have provided clear warnings regarding spread of non-native invasive species through artificial waterways, these lessons have been largely ignored by governments when resolving water scarcity problems. Here we use SNWTP, which will likely facilitate spread of invasive golden mussels, as well as many known examples of non-native invasive species spread through artificial waterways in other water systems, to call on governments to formally establish policy and seek management solutions to considering spread of non-native species when planning water diversions.

Keywords Golden mussel Limnoperna fortunei . Invasive species - Water scarcity · Water transfer

The world is facing a fresh water crisis in which this essential resource is often not available in sufficient quantity in areas where it is needed most. The United Nations considers an area as suffering from 'absolute water scarcity' if the per capita availability is below $500 \mathrm{~m}^{3}$ year $^{-1}$. Water scarcity currently affects approximately one-fifth of the world's population ( $\sim 1.2$ billion people), with another 500 million people in areas approaching absolute water scarcity. By 2025, 1.8 billion people are expected to live in 
countries/areas with absolute water scarcity (United Nations water scarcity http://www.un.org/waterfor lifedecade/scarcity.shtml).

Water diversions have been built around the world for millennia. Beginning in the nineteenth century, modern water diversions have been created to alleviate water scarcity, generation of hydropower, and rarely for discharge of sewage (Table 1). Among these reasons, the alleviation of water scarcity is the most common one (Table 1). Many countries/areas suffering from regional water scarcity have created diversions to transfer water from areas of relative abundance to those of relative scarcity (Table 1). California, for example, has created a series of diversions to move water from northern and eastern areas to arid southwest regions of the state (Israel and Lund 1995). Although water diversions have contributed significantly to development in many countries, such as growth of Denver and Los Angeles in the USA, the Green Revolution in India, and hydropower supply in Canada, they typically involve a number of adverse ecological impacts, including direct habitat loss and/or transformation and movement of contaminants between regions (Table 1). While these impacts are relatively straightforward and well realized, less attention has been paid to inter-basin movements of non-native species facilitated by water diversions (but see Galil 2000; Leuven et al. 2009). Here we define nonnative species as those that historically have never occurred in a particular region and differentiate them from invasive species, which we define as high impact species.

Nearly all proposed water diversions are located in developing countries, and are designed to alleviate water scarcity (e.g. Ghassemi and White 2007). Here we use China as a case study to highlight the biological invasion problem that may be associated with water diversions. We also explore unexpected consequences associated with spread of non-native, invasive species through artificial waterways in other water systems, and call on governments worldwide to formally establish policy and seek management solutions to considering the consequences with respect to biological invasions when new diversions are initially proposed.

China is among the many countries affected by regional water scarcity owing to both demographic and climate changes. China's human population has experienced dramatic growth in the latter half of the twentieth century, which when coupled with rapid urbanization resulted in some of the world's largest metropolises (e.g. Beijing, Shanghai and Tianjin). For example, Beijing's official population increased from 4.2 million in 1949 to 21.2 million in 2013 (Fig. 1). Concomitant with this demographic change, China has experienced regional climate change, particularly in the northern part of the country (Ding et al. 2007; Wei and Chen 2009; Piao et al. 2010). Total precipitation in Beijing declined from an average of $419 \mathrm{~mm}$ between 1960 and 1990 to $371 \mathrm{~mm}$ between 1990 and 2009 (Climate change Knowledge Portal, available at http:// sdwebx.worldbank.org/climateportal/index.cfm?page= country_historical_climate\&ThisRegion=Asia\&This CCode $=\mathrm{CHN}$ ). Since the mid-1990s, Beijing and neighbouring Tianjin have also experienced an increase from two to six in the number of days per year in which maximum temperature exceeds $35^{\circ} \mathrm{C}$ (Wei and Chen 2009). The decline in precipitation as a result of climate change coupled with a general increase in water demand due to population growth and rapid urbanization has resulted in severe water scarcity in the Beijing area (Vörösmarty et al. 2010).

The distribution of water resources is highly skewed geographically in China, with per capita use being about four times higher in monsoon-affected areas south of the Yangtze River than those in the north (Yang and Pang 2006). Water utilization rates vary accordingly, from 1.7-19.5\% of available stream flow for watersheds in the south to 31.0-91.7\% in the north (Jiang 2009). Total per capita water availability in major cities in northern China is extremely low, with Beijing averaging only $170 \mathrm{~m}^{3}$ (Fig. 1), far below the United Nations' absolute water scarcity threshold.

Water shortages in China are particularly acute in the northern Hai and Yellow River basins. Ocean discharge has declined from 24 to 1 billion $\mathrm{m}^{3}$ per year for the former (Jiang 2009), and from 48 to 13 billion $\mathrm{m}^{3}$ per year for the latter since the $1950 \mathrm{~s}$ (Wang et al. 2006). Given the increasing scarcity of water in the north, it is not surprising that per capita water use in Beijing has declined sharply mainly due to water availability over the past 10 years (Fig. 1). In contrast to conditions in northern China, the Yangtze River in the south averages 960 billion $\mathrm{m}^{3}$ of runoff to the sea, setting the stage for possible water diversions.

The concept of water diversion in China was developed decades ago, but in 1998 the government initiated plans to address the regional water scarcity crisis with its Water Agenda 21 (Yang and Pang 2006). Central to this plan is the goal to increase overall 


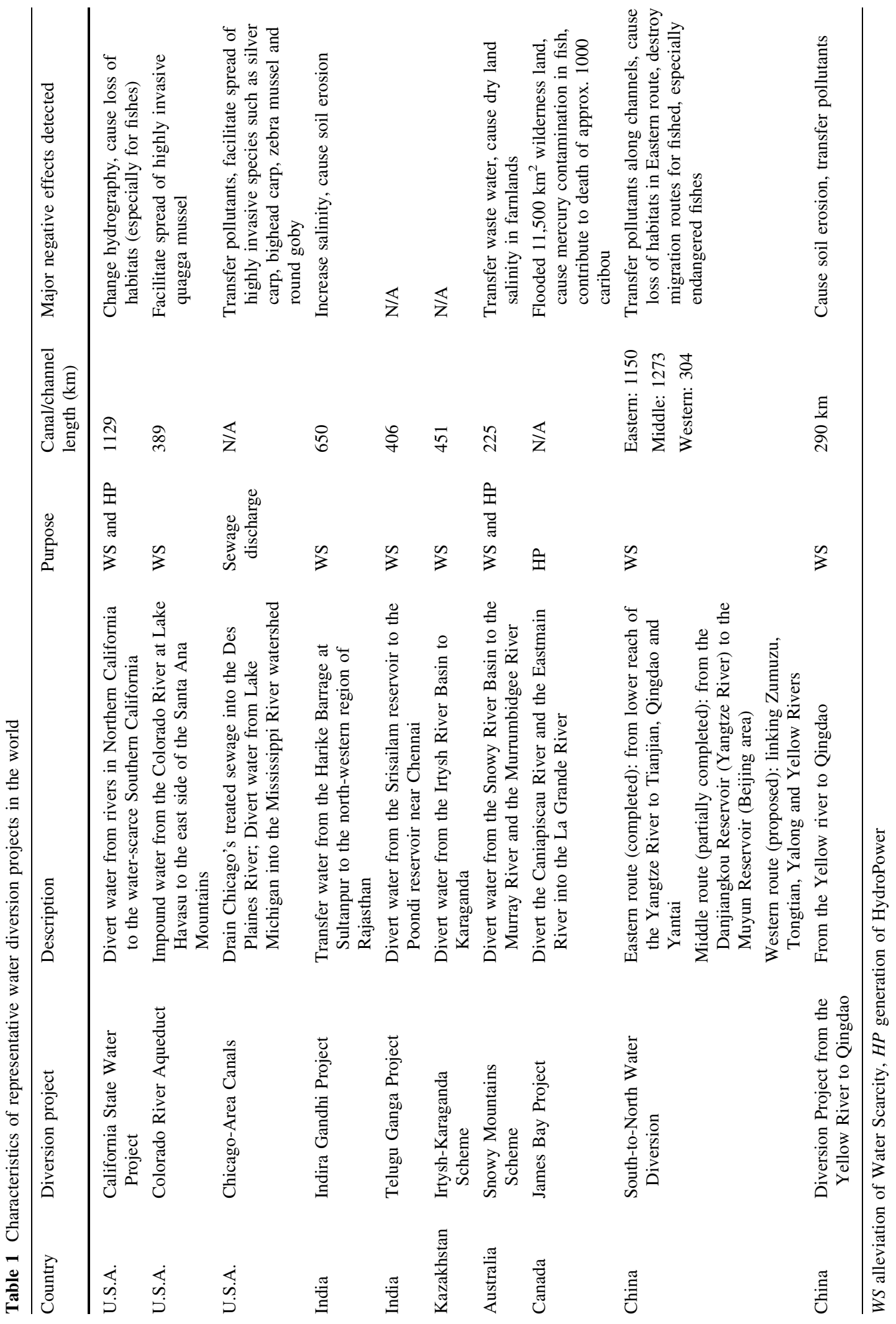


Fig. 1 Population growth from 1949 to 2013 (left) and water consumption per capita (right) from 2004 to 2013 in Beijing

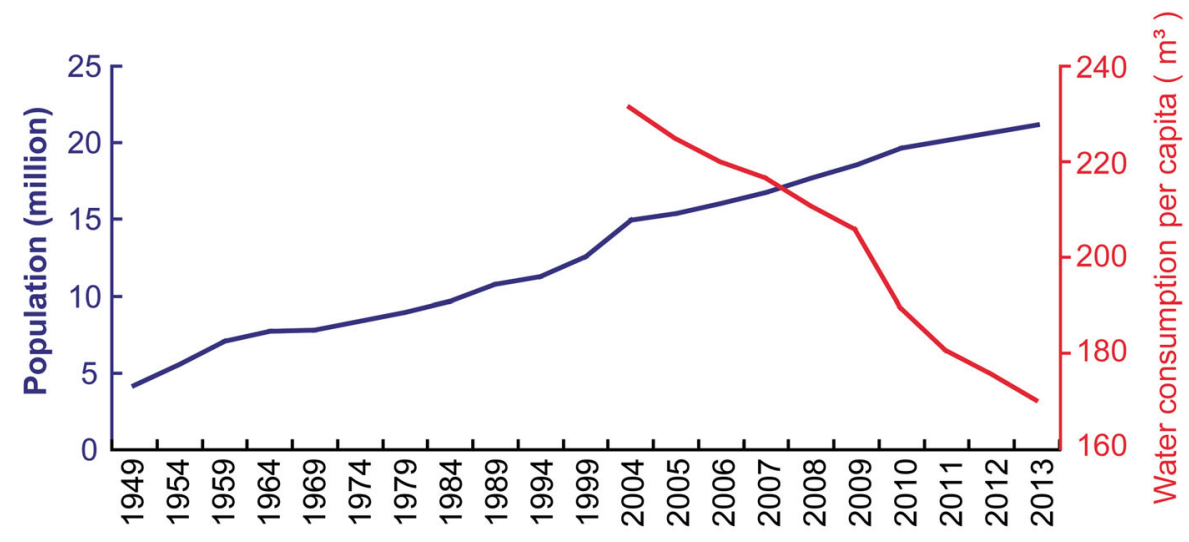

Year
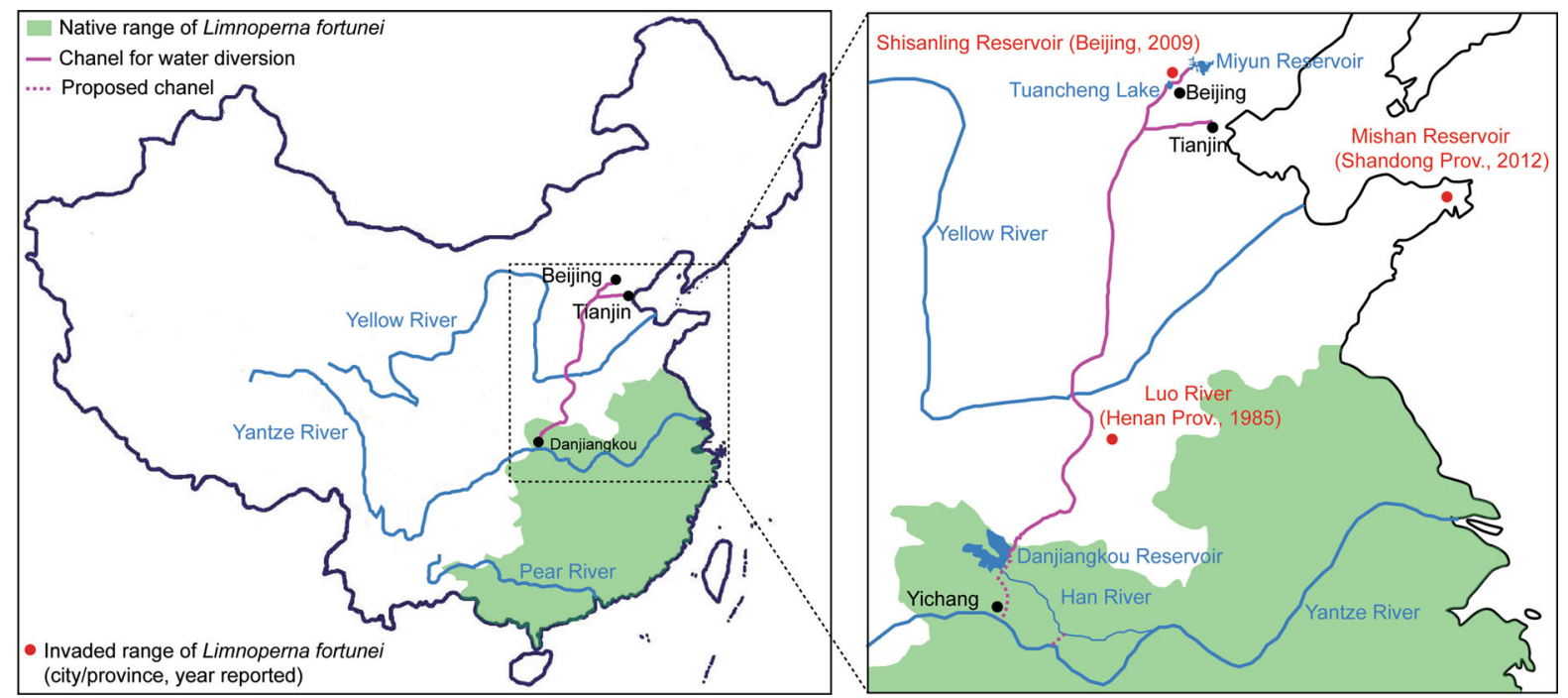

Fig. 2 The world's largest water transfer project in China, i.e. the South-to-North Water Diversion Project (the middle route is shown), portends spread of mass invaders, such as the golden mussel Limnoperna fortunei, a bivalve species causing severe biofouling problems

quantity in the north while reducing annual variation and seasonal fluctuations in water availability across the country, thereby reducing the frequency and scale of northern droughts and southern floods (Yang and Pang 2006). Chief among these initiatives was the South-to-North Water Transfer Project, the world's largest water diversion. This \$62US billion project will divert up to 45 billion $\mathrm{m}^{3}$ of water per year from water-rich areas in the south to arid areas in the north (Yang and Pang 2006). The project consists of three diversions - the western, middle and eastern routescorresponding with upper, middle and lower sections of the Yangtze River basin, the source of the diversion.
Among the three routes, the middle one is the longest $(1273 \mathrm{~km})$, beginning at China's second largest reservoir-the Danjiangkou-in the south and heading north to the Miyun Reservoir, the Beijing's principal water source (Fig. 2). Water diverted from the Han and Dan rivers will be stored in the Danjiangkou Reservoir and sent north using a series of gravity-fed channels and tunnels across the Upper Huai and Yellow rivers, before branching and terminating in Beijing and Tianjin.

The middle route has begun operation in autumn 2014 and the diverted water is expected to release to the Miyun Reservoir in summer-autumn 2015, 
providing up to 20 billion $\mathrm{m}^{3}$ of water per year when fully developed. This water transfer project may, however, result in a number of unexpected consequences, including spread of non-native invasive species. One example is the golden mussel Limnoperna fortunei, which is a biofouling mollusc native to the Pear River and middle-low reaches of the Yangtze River in China, Thailand, Korea, Laos, Cambodia and Vietnam (Ricciardi 1998; Zhan et al. 2012; Paolucci et al. 2014). The species has spread to many other areas, including some localities in north China, Hong Kong, Taiwan and Japan (Xu 2012; Boltocskoy 2015). Golden mussels were also discovered in 1990 in the Rio de la Plata estuary near Buenos Aires, Argentina, and have since colonized almost $2000 \mathrm{~km}$ of the Paraná River and adjacent waterways in a wave of mass invasions (Boltocskoy 2015).

We confirmed presence of the golden mussel in the Danjiangkou Reservoir in June 2014 based on both morphological and genetic characteristics using the cytochrome $c$ oxidase subunit I (COI) gene. The species forms large populations on the underside of floating docks as well as along the rocky shoreline of the reservoir. However, comprehensive field surveys and questionnaires of employees at the Miyun Reservoir have revealed that the species is not yet present in this system.

The golden mussel has a biphasic life cycle, with sedentary adults and planktonic veliger larvae. The species is easily spread by adults biofouled on vessel hulls, or veliger transfer in water currents and/or in ballast water of vessels (Ricciardi 1998; Paolucci et al. 2014; Boltocskoy 2015). The South-to-North Water Transfer Project will provide excellent dispersal opportunities for the mussel to colonize the concrete-lined canal downstream, raising the risk of serious biofouling problems throughout the middle route. Golden mussels are among the world's worst biofouling species in industrial and municipal water works (Nakano and Strayer 2014), including in the Shisanling Reservoir north of Beijing (Xu 2012), as well as in Hong Kong (Morton 1982), Japan (Magara et al. 2001) and South America (Boltocskoy 2015). Indeed, serious biofouling problems by this species have already occurred in another water transfer project from the Dong River-a branch of the Pear River-to Shenzhen (Xu 2012), a city with more than 13 million residents in southeastern China. Directional flow in canals and pipelines will likely limit upstream dispersal to the most vagile species, whereas a suite of species are expected to move passively or actively in currents downstream (Table 2).

Many examples and previous experiences in other systems provide clear warnings that constructed aquaducts, canals and pipelines provide opportunities for spread of invasive species (Table 2). For example, water is supplied to both Los Angeles and San Diego from the lower Colorado River below Lake Mead, a system now colonized by biofouling quagga mussels (Dreissena bugensis rostriformis) (e.g. Hickey 2010). The Chicago Area Waterway was constructed more than 100 years ago linking Lake Michigan and the Mississippi River. This conduit has permitted invasive species to move south from the Great Lakes, and may yet allow invasive silver carp (Hypophthalmichthys molitrix) and bighead carp (Hypophthalmichthys nobilis) to spread in the opposite direction (e.g. Jerde et al. 2013). Although scientists warned that invasive species could spread through the Main-Danube canal, this canal was still opened, and unfortunately this canal has served as an "invasive highway" (Leuven et al. 2009). By using this "invasion highway" and other invasion corridors, a total of 45 non-indigenous macro-invertebrate species have been recorded in the Rhine basin, and the average number of invasions per decade shows a sharp increase from $<1$ to 13 species (Leuven et al. 2009). Perhaps, the most notorious example of mass biological invasion unfolded followed opening of the Suez Canal, which allowed myriad species from the Red Sea to colonize the eastern Mediterranean Sea (Galil 2000; Gollasch 2006). Migration of species through the Suez Canal accounts for more species introductions in the eastern Mediterranean Sea $(24.5 \%)$ than ballast water (22.3\%) and hull fouling (16.5\%; Gollasch 2006). Plans to build a replicate canal adjacent to the Suez Canal will exacerbate an existing problem (Galil et al. 2014), as this vector, while largely unidirectional, is nevertheless large-scale in nature, perpetual, and relatively non-selective with respect to the types of species that may be spread using it. Similarly, a large number of highly invasive species have successfully utilized canals to spread throughout Europe (see Leuven et al. 2009). For example, the Main-Danube canal has allowed a series of high impact invaders to spread from the Danube River basin to the lower Rhine River basin. Mass transfer of many species holds particular risk, as sampling theory suggests that introductions of multiple species pose a greater 


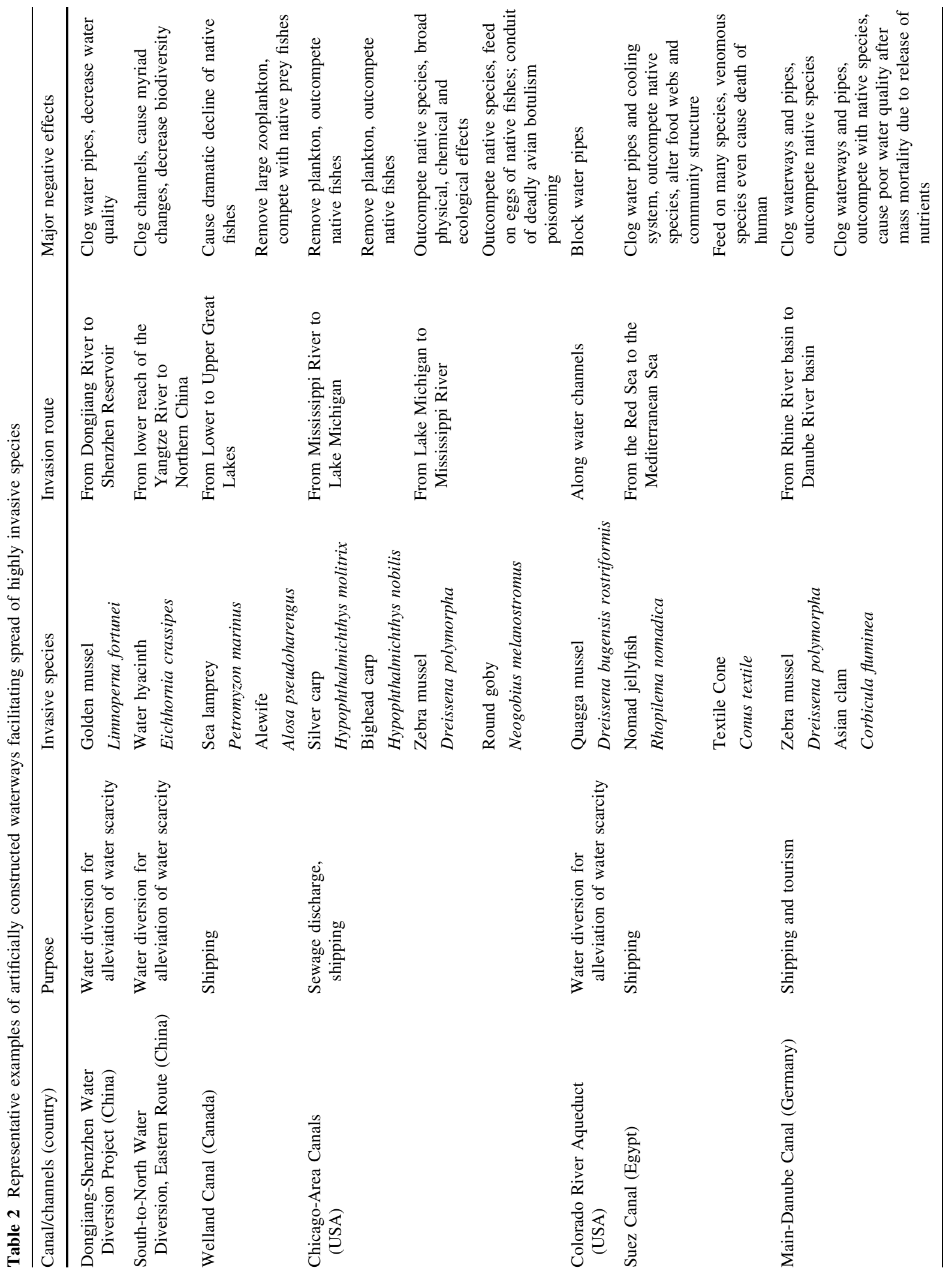




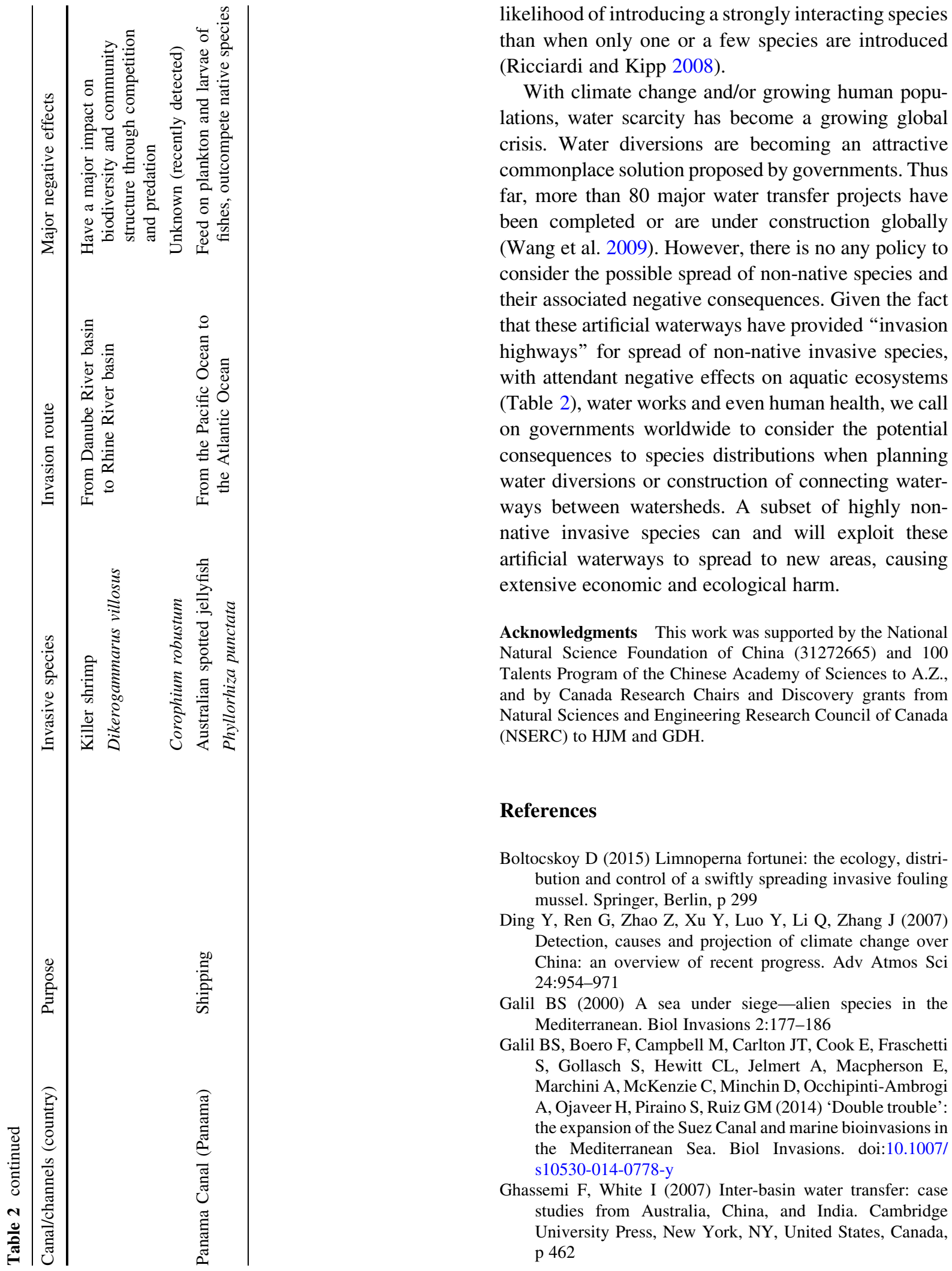


Gollasch S (2006) Overview on introduced aquatic species in European navigational and adjacent waters. Helgol Mar Res 60:84-89

Hickey V (2010) The quagga mussel crisis at Lake Mead national recreation area, Nevada (U.S.A.). Conserv Biol 24:931-937

Israel M, Lund JR (1995) Recent California water transfers: implications for water management. Nat Resour J 1:21-29

Jerde CL, Chadderton WL, Mahon AR, Renshaw MA, Corush J, Budny ML, Mysorekar S, Lodge DM (2013) Detection of Asian carp DNA as part of a Great Lakes basin-wide surveillance program. Can J Fish Aquat Sci 70:522-526

Jiang Y (2009) China's water scarcity. J Environ Manage 90:3185-3196

Leuven RSEW, van der Velde G, Baijens I, Snijders J, van der Zwart C, Lenders HJR, bij de Vaate A (2009) The river Rhine: a global highway for dispersal of aquatic invasive species. Biol Invasions 11:1989-2008

Magara Y, Matsui Y, Goto Y, Yuasa A (2001) Invasion of the non-indigenous nuisance mussel, Limnoperna fortunei, into water supply facilities in Japan. J Water Supply Res Technol Aqua 50:113-124

Morton B (1982) The reproductive cycle in Limnoperna fortunei (Dunker, 1857) (Bivalvia: Mytilidae) fouling Hong Kong's raw water supply system. Oceanol Limnol Sin 13:312-325

Nakano D, Strayer DL (2014) Biofouling animals in fresh water: biology, impacts, and ecosystem engineering. Front Ecol Environ 12:167-175

Paolucci EM, Sardiña P, Sylvester F, Perepelizin PV, Zhan A, Ghabooli S, Cristescu ME, Oliveira MD, MacIsaac HJ (2014) Morphological and genetic variability in an alien invasive mussel across an environmental gradient in South America. Limnol Oceanogr 59:400-412

Piao S, Ciais P, Huang Y, Shen Z, Peng S, Li J, Zhou L, Liu H, Ma Y, Ding Y, Friedlingstein P, Liu C, Tan K, Yu Y, Zhang
T, Fang J (2010) The impacts of climate change on water resources and agriculture in China. Nature 467:43-51

Ricciardi A (1998) Global range expansion of the Asian mussel Limnoperna fortunei (Mytilidae): Another fouling threat to freshwater systems. Biofouling 13:97-106

Ricciardi A, Kipp R (2008) Predicting the number of ecologically harmful exotic species in an aquatic system. Divers Distrib 14:374-380

Vörösmarty CJ, McIntyre PB, Gessner MO, Dudgeon D, Prusevich A, Green P, Glideen S, Bunn SE, Sullivan CA, Liermann CR, Davies PM (2010) Global threats to human water security and river biodiversity. Nature 467:555-561

Wang H, Yang Z, Saito Y, Liu JP, Sun X (2006) Interannual and seasonal variation of the Huanghe (Yellow River) water discharge over the past 50 years: connections to impacts from ENSO events and dams. Global Planet Change 50:212-225

Wang G, Ouyang Q, Zhang Y (2009) Water transfer projects in the world. Scientific Press, Beijing, China

Wei K, Chen W (2009) Climatology and trends of high temperature extremes across China in summer. Atmos Ocean Sci Lett 2:153-158

Xu M (2012) Experimental study of macroinvertebrate Limnoperna fortunei invasion and prevention in water transfer tunnels. Ph.D. thesis of Qinghua University, Beijing, China (in Chinese with English abstract)

Yang X, Pang J (2006) Implementing China's "Water Agenda 21". Front Ecol Environ 4:362-368

Zhan A, Perepelizin PV, Ghabooli S, Paolucci E, Sylvester F, Sardiña P, Cristescu ME, MacIsaac HJ (2012) Scale-dependent post-establishment spread and genetic diversity in an invading mollusc in South America. Diver Distrib 18:1042-1055 